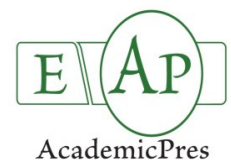

\title{
Combined Use of Green Manure and Farmyard Manure Allows Better Nutrition of Organic Lettuce
}

\author{
Sevgi CALISKAN ${ }^{1 *}$, Halit YETISIR ${ }^{2}$, Sema KARANLIK ${ }^{3}$ \\ ${ }^{1}$ Department of Plant Production and Technologies, Nigde University, 51240, Nigde, Turkey; scaliskan@nigde.edu.tr ( ${ }^{*}$ corresponding author) \\ ${ }^{2}$ Erciyes University, Faculty of Agriculture, Department of Horticulture, Kayseri, Turkey; yetisir1@erciyes.edu.tr \\ ${ }^{3}$ Mustafa Kemal University, Faculty of Agriculture, Department of Soil Science, 31000 Hatay, Turkey; karanlik.sema@gmail.com
}

\begin{abstract}
Organic crop production has become a major business due to rising consumer demand, price premiums and increasing market opportunities. A field experiment was conducted to compare organic and conventional production systems by evaluating growth, yield and mineral content of lettuce leaves. Six organic productions systems, green manure (GM), farmyard manure (FYM), commercial organic fertilizer (COF) and their combinations were compared with conventional production system (CPS). A non-fertilized control treatment was also included. Plant growth and yield were found higher in the organic production system compare to conventional production system. The lowest plant growth and yield were obtained in the control treatment. Values of vitamin $\mathrm{C}$ content of lettuce grown in the organic production systems were higher than those of the conventional production system. The highest lettuce yield (71.8 and $\left.76.5 \mathrm{t} \mathrm{ha}^{-1}\right)$ was obtained with GM + FYM treatment. The results indicated that combined use of green manure and farmyard manure can be successfully used in organic lettuce production.
\end{abstract}

Keywords: mineral content, plant nutrition, quality, yield, Lactuca sativa L.

\section{Introduction}

Lettuce (Lactuca sativa L. var. longifolia), as a Mediterranean vegetable, is the major salad crop to be cultivated and commercialized internationally (Deshpande and Solunkhe, 1998). It is grown as a leafy vegetable and is usually consumed as raw in salads, hamburgers tacos and a number of other dishes. Leafy vegetables have an important role in human nutrition and are a good source of minerals. It is a leafy cool-season vegetable with a worldwide production area of $1,110,720$ ha and production of $24,324,716 \mathrm{t}$ in 2011 (FAO, 2013). It is commonly produced in the Mediterranean-type environments in Turkey (Kamberoglu and Alan, 2011).

The quality and quantity of applied fertilizers are key factors affecting the growth, yield and quality of plants. Generally, excessive mineral fertilizers are applied to vegetables in order to achieve a maximum yield (Stewart $e t$ al., 2005). Especially, the excess amount of nitrogen $(\mathrm{N})$ fertilizer increases nitrite accumulation in plant leaves and this could result negative impact on human health (Islam et al., 2012). In recent years, organic farming, which requires utilization of organic fertilizers, has gained popularity to eliminate the negative effects of mineral fertilizers for human health. In organic farming systems, plants are grown without the use of chemical fertilizers, pesticides, fungicides and herbicides. They are usually fertilized solely with organic fertilizers, such as green manures, farmyard manure, crop residues, commercial organic fertilizers or organic wastes. These components maintain soil productivity, supply plant nutrients and help in combination with biological pest management to control insects, weeds and other pests (Polat et al., 2008; Hammad et al., 2011; Talgre et al., 2012). Worthington (2001) showed that organically grown fruits or vegetables contain more mineral and vitamins than conventionally grown fruits or vegetables. The results of previous studies revealed that organically grown lettuce had higher content of vitamin $\mathrm{C}$, iron $(\mathrm{Fe})$, magnesium $(\mathrm{Mg})$, and phosphorus $(\mathrm{P})$ than the conventionally grown ones. Furthermore, Kelly and Bateman (2010) examined the mineral content of organically grown tomato and found more copper $(\mathrm{Cu})$, calcium $(\mathrm{Ca})$, zinc $(\mathrm{Zn})$, Rubidium $(\mathrm{Rb}), \mathrm{Mg}$ and Fe than in conventional fruit. Citak and Sonmez (2009) investigated the mineral contents of organically and conventionally grown spinach during two successive seasons and reported that the micro nutrient content of spinach was higher with organic fertilizer than compare to mineral fertilizer applications.

The aim of this research was to compare the yield and some of the physico-chemical properties and mineral content of lettuce grown in conventional and organic production systems. Green manure, farmyard manure, commercial organic fertilizer and their combinations were used as plant nutrient sources in the organic production system. 


\section{Materials and methods}

\section{Location and experimental design}

A two-years field experiment were conducted at Mustafa Kemal University, Experimental Farm of Agricultural Faculty in Hatay (36 $39^{\circ} \mathrm{N}, 36^{\circ} 40^{\prime} \mathrm{E}$; $83 \mathrm{~m}$ elevation) located in the Eastern Mediterranean region of Turkey. The experimental area had not been cultivated for five years before the research. Five organic production systems, which utilized green manure (GM), farmyard manure (FYM) and commercial organic fertilizer (COF) alone and in combination were compared with a conventional production system (CPS) for lettuce production. A nonfertilized treatment was also included as control. The field experiments were established as a randomized block design with three replications. The each plot had $100 \mathrm{~m}^{2}$ area $(10 \mathrm{x}$ $10 \mathrm{~m}$ ) and consisted of 25 rows $0.4 \mathrm{~m}$ apart. The traditional growing plots were established nearly $200 \mathrm{~m}$ away from organic production plots at the same experimental unit.

The FYM was obtained from livestock farm of Mustafa Kemal University and applied at $30 \mathrm{t} \mathrm{ha}^{-1}$ a week before transplanting. Some general characteristics of used FYM were given in Tab. 1. The green manure plant, common vetch (Vicia sativa L.) was sown as $100 \mathrm{~kg} \mathrm{ha}^{-1}$. The common vetch plants were cut above soil level at flowering stage and were incorporated into the soil (at the rate of $27 \mathrm{t}$ $\mathrm{ha}^{-1}$ in the first year, and $31 \mathrm{t} \mathrm{ha}^{-1}$ in the second year). Poultry manure used as the commercial organic fertilizer (COF) study, was organic, in pellet form (Tab. 1).

Tab. 1. Chemical characteristics of soil, farmyard manure and commercial organic fertilizer used in the experiment

\begin{tabular}{cccccccc}
\hline $\begin{array}{c}\text { Produc- } \\
\text { tion } \\
\text { systems }\end{array}$ & $\begin{array}{c}\text { E.C. } \\
\left(\mathrm{mScm}^{1}\right)\end{array}$ & $\mathrm{pH}$ & $\begin{array}{c}\mathrm{CaC}_{3} \\
(\%)\end{array}$ & $\begin{array}{c}\mathrm{O} . \mathrm{M} \\
.(\%)\end{array}$ & $\begin{array}{c}\mathrm{N} \\
(\%)\end{array}$ & $\begin{array}{c}\mathrm{P} \\
(\mathrm{mg} \\
\left.\mathrm{kg}^{1}\right)\end{array}$ & $\begin{array}{c}\mathrm{K} \\
(\mathrm{mg} \\
\left.\mathrm{kg}^{1}\right)\end{array}$ \\
\hline Soil & 1.0 & 7.8 & 21.7 & 1.73 & 0.13 & 305 & 253 \\
FYM & 38.5 & 8.7 & 39.0 & 55.0 & 2.35 & 5800 & 26,000 \\
COF & 5.0 & 6.4 & 3.0 & 9.96 & 2.69 & 21,500 & 19,000 \\
\hline
\end{tabular}

The choice of commercial organic fertilizer and application rate was based on a previous study (Vural et al., 2000), in which the fertilizer was approved for organic vegetable growing. For the mineral fertilizer, the total amount of phosphorus ( $60 \mathrm{~kg} \mathrm{P} \mathrm{ha}^{-1}$ as super phosphate) and potassium (60 kg K ha ${ }^{-1}$ as potassium sulphate) and one-third of nitrogen (80 kg N ha ${ }^{-1}$ as ammonium nitrate) fertilizers were applied before planting. The remaining two thirds of the nitrogen fertilizer was side dressed in two parts during the growing season. The soil used in this study was clayey and some chemical properties of the soil $(0-40 \mathrm{~cm}$ depth), FYM and COF are given Tab. 1.

The experimental site has a typical Mediterranean climate conditions with hot-dry summers and mild-rainy winter in both years. The mean temperatures were ranged between $7.6{ }^{\circ} \mathrm{C}$ (January) and $15.9{ }^{\circ} \mathrm{C}$ (April) in the first year, and between $5.6^{\circ} \mathrm{C}$ (January) and $19.1^{\circ} \mathrm{C}$ (April) in the second year. The total rainfall during experimental periods were $569 \mathrm{~mm}$ and $391 \mathrm{~mm}$ in the experimental years, respectively.

\section{Cultivation}

The lettuce seedlings cv. 'Marco' were pre-grown in plastic multiport trays filled with a mixture of peat and perlite $(1: 1, \mathrm{v} / \mathrm{v})$ and grown in a greenhouse. Multipot trays were irrigated twice a day with tap water. Plants with three true leaves were transplanted to the soil in an open field at a density of 7 plants $\mathrm{m}^{-2}$ on December 10 and on January 2 in the first and second years, respectively. The planting was done by hand and, immediately after transplanting, plants from all treatments were irrigated by a drip irrigation system. Plants were harvested when they reached approximately their highest commercial size in both years. The harvest dates were April 17 and May 5 in the experimental years, respectively.

\section{Analytical methods}

Ten plants were chosen randomly from each treatment for physical analysis before the harvest. Head height $(\mathrm{cm})$, stem diameter $(\mathrm{mm})$ and head weight $(\mathrm{g})$ were determined. For mineral analysis, fresh weight ( $\mathrm{fw}$ ) of the harvested ten plants was weighed and then the wrapper leaves were removed. The leaves of lettuce were rinsed with distilled water after washing with tap water and then, blotted dry with paper towels. The leaves were dried in an air-forced oven at $80^{\circ} \mathrm{C}$ to a constant weight. The dried samples were ground to pass 20 mesh sieve, and kept in clean glass bottles for analysis. Nutrient $(\mathrm{Cu}, \mathrm{Fe}, \mathrm{Mn}$ and $\mathrm{Zn}$ ) content of leaves was analysed using atomic absorption spectrophotometer (Kacar and Inal, 2008). Total $\mathrm{N}$ content of the lettuce samples were analysed by a modified Kjeldahl method (Nelson and Sommers, 1980). The $\mathrm{pH}$ was determined in a $50 \mathrm{ml}$ filtrate obtained from a mixture of $10 \mathrm{~g}$ material blended with $100 \mathrm{ml}$ deionized water of fresh leaf tissue and vitamin C was determined according to Pearson (1970). Total soluble solids (TTS) content was measured in the juice of leaves using a digital refractometer (Atago model ATC-1E).

\section{Statistical methods}

Data for each year were statistically analysed using a standard analysis of variance technique for randomized block design using the general linear model procedure in the Statistical Analysis System (SAS Institute 1996). The means were compared by Tukey's test $(\mathrm{p} \leq 0.05)$.

\section{Results}

\section{Yield and plant growth}

The head height, stem diameter, head weight and yield of lettuce grown under the organic and conventional production systems are presented in Tab. 2 . In general, the organic production systems resulted higher values than the conventional production system in both years. Head height and head diameter were measured as indicators of plant growth. Head height was significantly influenced by the treatments in both years (Tab. 2). Organic treatments $\mathrm{GM}+\mathrm{COF}$ and GM+FYM resulted in significantly higher head height than unfertilized control in the first growing season. The head height values of other organic treatments and conventional mineral fertilizer did not differ significantly than the unfertilized control or $\mathrm{GM}+\mathrm{COF}$ 
250

and GM+FYM treatments. In the second year, the GM+FYM treatment produced significantly higher head height than unfertilized control, conventional mineral fertilizer and sole use of FYM and COF. The organic treatments of GM and GM+COF had also greater head height than conventional control, but they did not significantly differ from other treatments.

The differences between treatments for head diameter were found significant only in the second year (Tab. 2). The head diameter was greater with organic treatments GM+FYM, GM+COF, GM and FYM than the unfertilized control in the second growing season. However, the COF did not differ among these treatments. Conventional mineral fertilizer also significantly increased the head diameter compare to unfertilized control, but it was not significantly different from other organic treatments except GM+FYM for head diameter.

Head weight was significant affected by the treatments, and differences among the treatments displayed more than $90 \%$ of the total variation (see test $\mathrm{R}^{2}$ values) in both years (Tab. 2). The heaviest head weights were obtained from GM + FYM treatment in both years while the lowest head weight values were obtained from the unfertilized control in both years. Head weight of the GM+COF treatment was grouped within the top values, and was significantly greater than unfertilized control and sole use of FYM and COF during the first year. The combined use of GM and COF was also found as productive, and after GM+FYM treatment it produced heavier head height than all other treatments except sole GM. Yields of the lettuce grown under the conventional and organic production systems are presented in Tab. 2. The results showed that lettuce yields were significantly affected by the production systems $(\mathrm{p} \leq 0.01)$, and differences between treatments displayed $91 \%$ and $86 \%$ of total variation (see test $R^{2}$ ) in the first and second year, respectively (Tab. 2). The yield values were ranged from 28.9 to $71.8 \mathrm{t} \mathrm{ha}^{-1}$ in the first year and from 40.7 to $76.5 \mathrm{t} \mathrm{ha}^{-1}$ in the second year. The highest values were obtained from the GM+FYM treatments in both years while the unfertilized control resulted in the poorest yield in corresponding years. Green manure treatment was found as very effective to improve lettuce yield especially when combined with FYM and COF comparing to conventional mineral fertilization or sole use of FYM and $\mathrm{COF}$ in both years.

\section{Physico-chemical properties}

The results for the main physico-chemical properties of the lettuce grown under the conventional and different organic production systems are presented in Tab. 3. Vitamin $\mathrm{C}, \mathrm{pH}$ and soluble solids were not significantly affected by the applied treatments in both conventional and organic production systems. Although the differences among treatments were not significant for vitamin C content, all organic treatments had slightly higher Vitamin $\mathrm{C}$ content than conventional production system in the first year. However, similar trend was not recorded in the second year, and some organic treatments (Control, COF and GM) resulted with slightly lower vitamin $\mathrm{C}$ content than conventional production system. There were no significant differences in $\mathrm{pH}$ and soluble solids between organically and conventionally grown lettuce plants (Tab. 3).

\section{Nutrient element contents}

The total $\mathrm{N}$ contents of the lettuce leaves were not significantly influenced by the treatments in both conventional and organic production system in both years (Tab. 3). In general, the total $\mathrm{N}$ content of lettuce leaves in organic production systems was higher than in the conventional production system. Control treatment had the highest total $\mathrm{N}$ content (1.58 and 2.60\% in 2007 and 2008 respectively) compared with the treatments in the organic production system.

The total $\mathrm{Cu}, \mathrm{Fe}, \mathrm{Mn}$ and $\mathrm{Zn}$ contents of the lettuce leaves grown under the conventional and organic production systems are presented in Tab. 4. The results showed that $\mathrm{Cu}$ contents of lettuce leaves were significantly affected by the treatments in both years. The GM+COF

Tab. 2. Effects of conventional and organic production systems on head height, head diameter, head weight and yield of lettuce

\begin{tabular}{|c|c|c|c|c|c|c|c|c|}
\hline \multirow{2}{*}{ Treatment } & \multicolumn{2}{|c|}{ Head height $(\mathrm{cm})$} & \multicolumn{2}{|c|}{ Head diameter $(\mathrm{mm})$} & \multicolumn{2}{|c|}{ Head weight $(\mathrm{g})$} & \multicolumn{2}{|c|}{ Yield (kg/da) } \\
\hline & Year 1 & Year 2 & Year 1 & Year 2 & Year 1 & Year 2 & Year 1 & Year 2 \\
\hline Conventional & $27.8^{\mathrm{ab}}$ & $24.8^{c}$ & 33.8 & $32.6^{\mathrm{bc}}$ & $820.7^{b c}$ & $837.0^{\mathrm{de}}$ & $51.3^{\mathrm{bc}}$ & $52.3^{\text {bcd }}$ \\
\hline Control & $26.1^{\mathrm{b}}$ & $26.5^{b c}$ & 31.1 & $28.2^{\mathrm{d}}$ & $462.7^{\mathrm{d}}$ & $652.3^{f}$ & $28.9^{d}$ & $40.7^{\mathrm{d}}$ \\
\hline$F Y M$ & $29.7^{\mathrm{ab}}$ & $27.3^{b c}$ & 40.8 & $34.7^{a b}$ & $745.7^{c}$ & $926.7^{\mathrm{cd}}$ & $46.6^{c}$ & $57.9^{\mathrm{bcd}}$ \\
\hline$C O F$ & $28.0^{\mathrm{ab}}$ & $26.0^{\mathrm{bc}}$ & 29.6 & $29.3^{\mathrm{cd}}$ & $717.3^{\mathrm{cd}}$ & $767.0^{\text {ef }}$ & $44.8^{\mathrm{cd}}$ & $47.9^{\mathrm{cd}}$ \\
\hline$G M$ & $30.5^{\mathrm{ab}}$ & $30.5^{\mathrm{ab}}$ & 32.6 & $35.5^{\mathrm{ab}}$ & $852.3^{b c}$ & $973.0^{b c}$ & $53.3^{b c}$ & $60.8 \mathrm{abc}$ \\
\hline$G M+F Y M$ & $31.8^{a}$ & $32.3^{\mathrm{a}}$ & 38.5 & $38.7^{a}$ & $1149.0^{\mathrm{a}}$ & $1225.7^{\mathrm{a}}$ & $71.8^{\mathrm{a}}$ & $76.5^{a}$ \\
\hline$G M+C O F$ & $32.2^{\mathrm{a}}$ & $30.3^{\mathrm{ab}}$ & 36.6 & $36.5^{\mathrm{ab}}$ & $1060.3^{\mathrm{ab}}$ & $1069.0^{b}$ & $66.3^{\mathrm{ab}}$ & $66.8^{\mathrm{ab}}$ \\
\hline Treatment MS & $15.3^{* *}$ & $23.2^{* *}$ & $50.1^{\mathrm{ns}}$ & $44.4^{* *}$ & $155069^{* *}$ & $110206^{* *}$ & $605.3^{* *}$ & $429.8^{* *}$ \\
\hline Test $\mathrm{R}^{2}$ & 0.75 & 0.82 & 0.53 & 0.90 & 0.91 & 0.96 & 0.91 & 0.86 \\
\hline $\mathrm{CV}$ & 5.5 & 5.6 & 14.8 & 4.6 & 10.8 & 5.1 & 10.7 & 10.6 \\
\hline
\end{tabular}

FYM - Farmyard manure; COF - Commercial organic fertilizer; O.M. - Organic matter.

ns, $\left({ }^{*}\right),\left(^{* *}\right)$ - not significant or significant at $P \leq 0.05$ or 0.01 , respectively.

Within a column, means followed by the same letter are not significantly different $(\mathrm{p}=0.05)$ using Tukey's test. 
Tab. 3. Some physicochemical properties and total $\mathrm{N}$ content of lettuce grown under conventional and organic production systems

\begin{tabular}{|c|c|c|c|c|c|c|c|c|}
\hline \multirow{2}{*}{ Treatment } & \multicolumn{2}{|c|}{ Vitamin C $\left({\left.\mathrm{mg} 100 \mathrm{~g}^{-1}\right)}^{-1}\right.$} & \multicolumn{2}{|c|}{$\mathrm{pH}$} & \multicolumn{2}{|c|}{ Soluble solids (\%) } & \multicolumn{2}{|c|}{ Total N (\%) } \\
\hline & Year 1 & Year 2 & Year 1 & Year 2 & Year 1 & Year 2 & Year 1 & Year 2 \\
\hline Conventional & 5.60 & 8.13 & 5.83 & 5.97 & 4.67 & 4.87 & 1.97 & 2.01 \\
\hline Control & 6.73 & 7.33 & 5.93 & 5.77 & 4.00 & 4.80 & 2.58 & 2.60 \\
\hline$F Y M$ & 7.63 & 8.30 & 5.87 & 5.77 & 4.33 & 4.97 & 2.32 & 2.37 \\
\hline$C O F$ & 7.10 & 7.67 & 5.83 & 5.80 & 4.67 & 4.87 & 2.32 & 2.36 \\
\hline$G M$ & 6.30 & 7.70 & 5.87 & 5.83 & 4.33 & 4.33 & 2.38 & 2.43 \\
\hline$G M+F Y M$ & 6.70 & 9.30 & 5.90 & 5.77 & 4.33 & 4.83 & 2.35 & 2.42 \\
\hline$G M+C O F$ & 6.90 & 9.43 & 5.83 & 5.87 & 4.00 & 4.63 & 2.55 & 2.42 \\
\hline Treatment MS & $1.22^{\mathrm{ns}}$ & $2.00^{\mathrm{ns}}$ & $0.001^{\mathrm{ns}}$ & $0.016^{\mathrm{ns}}$ & $0.22^{\mathrm{ns}}$ & $0.14^{\mathrm{ns}}$ & $0.12^{\mathrm{ns}}$ & $0.09^{\mathrm{ns}}$ \\
\hline Test $\mathrm{R}^{2}$ & 0.57 & 0.60 & 0.58 & 0.56 & 0.43 & 0.62 & 0.51 & 0.59 \\
\hline $\mathrm{CV}$ & 10.2 & 11.2 & 0.8 & 1.4 & 13.0 & 5.1 & 10.3 & 7.7 \\
\hline
\end{tabular}

FYM - Farmyard manure; COF - Commercial organic fertilizer; O.M. - Organic matter.

$\mathrm{ns},\left({ }^{*}\right),\left({ }^{*}\right)$ - not significant or significant at $\mathrm{p} \leq 0.05$ or 0.01 , respectively.

Tab. 4. Effects of conventional and organic production systems on micro nutrient ( $\mathrm{Cu}, \mathrm{Fe}, \mathrm{Mn}$ and $\mathrm{Zn})$ content of lettuce leaves

\begin{tabular}{|c|c|c|c|c|c|c|c|c|}
\hline \multirow{2}{*}{ Treatment } & \multicolumn{2}{|c|}{$\mathrm{Cu}\left(\mathrm{mg} \mathrm{kg}^{-1}\right)$} & \multicolumn{2}{|c|}{$\mathrm{Fe}\left(\mathrm{mg} \mathrm{kg}^{-1}\right)$} & \multicolumn{2}{|c|}{$\operatorname{Mn}\left(\mathrm{mg} \mathrm{kg}^{-1}\right)$} & \multicolumn{2}{|c|}{$\mathrm{Zn}\left(\mathrm{mg} \mathrm{kg}^{-1}\right)$} \\
\hline & Year 1 & Year 2 & Year 1 & Year 2 & Year 1 & Year 2 & Year 1 & Year 2 \\
\hline Conventional & $12.3 \mathrm{c}$ & $16.0 \mathrm{c}$ & 108.0 & $65.0 c$ & $51.7 \mathrm{a}$ & $23.3 \mathrm{~d}$ & $21.0 \mathrm{~b}$ & $26.7 \mathrm{de}$ \\
\hline Control & $17.0 \mathrm{abc}$ & $21.3 \mathrm{a}$ & 144.3 & $145.7 \mathrm{a}$ & $42.7 \mathrm{ab}$ & $34.7 \mathrm{bc}$ & $30.0 \mathrm{ab}$ & $46.3 \mathrm{~b}$ \\
\hline$F Y M$ & $13.7 \mathrm{bc}$ & $18.3 \mathrm{~b}$ & 120.3 & $106.0 \mathrm{~b}$ & $37.0 \mathrm{ab}$ & $35.7 \mathrm{~b}$ & $26.7 \mathrm{ab}$ & $35.0 \mathrm{c}$ \\
\hline COF & $15.3 \mathrm{abc}$ & $22.3 \mathrm{a}$ & 119.0 & $69.3 c$ & $39.3 \mathrm{ab}$ & $27.0 \mathrm{~cd}$ & $29.3 \mathrm{ab}$ & $21.3 \mathrm{e}$ \\
\hline$G M$ & $15.0 \mathrm{abc}$ & $22.0 \mathrm{a}$ & 134.7 & $119.0 \mathrm{~b}$ & $38.0 \mathrm{ab}$ & $43.7 \mathrm{a}$ & $33.3 \mathrm{ab}$ & $34.0 \mathrm{~cd}$ \\
\hline$G M+F Y M$ & $21.3 \mathrm{ab}$ & $22.3 \mathrm{a}$ & 138.7 & $149.3 \mathrm{a}$ & $39.0 \mathrm{ab}$ & $34.7 \mathrm{bc}$ & $38.7 \mathrm{ab}$ & $55.7 \mathrm{a}$ \\
\hline$G M+C O F$ & $23.0 \mathrm{a}$ & $22.7 \mathrm{a}$ & 135.0 & $121.3 \mathrm{~b}$ & $35.3 \mathrm{~b}$ & $33.3 \mathrm{bc}$ & $41.7 \mathrm{a}$ & $51.3 \mathrm{ab}$ \\
\hline Treatment MS & $47.1^{* *}$ & $19.5^{* *}$ & $505.7 \mathrm{~ns}$ & $3359^{* *}$ & $89.1^{*}$ & $127.9^{* *}$ & $149.3^{*}$ & $493.9^{* *}$ \\
\hline Test $\mathrm{R}^{2}$ & 0.75 & 0.95 & 0.53 & 0.97 & 0.61 & 0.90 & 0.69 & 0.97 \\
\hline $\mathrm{CV}$ & 16.9 & 3.6 & 13.3 & 6.1 & 13.2 & 8.3 & 20.9 & 7.1 \\
\hline
\end{tabular}

FYM - Farmyard manure; COF - Commercial organic fertilizer; O.M. - Organic matter.

ns, $\left({ }^{*}\right),\left({ }^{* *}\right)$ - not significant or significant at $\mathrm{p} \leq 0.05$ or 0.01 , respectively.

Within a column, means followed by the same letter are not significantly different ( $\mathrm{p}=0.05)$ using Tukey's test.

treatment had significantly higher $\mathrm{Cu}$ content than sole FYM treatment and conventional mineral fertilization, but it considered within the same group with other treatments during the first year. The $\mathrm{Cu}$ content of lettuce leaves from different treatments divided into three distinct groups in the second year. The lowest $\mathrm{Cu}$ content was obtained from conventional production system while all organic treatments except sole FYM application grouped within group of the highest $\mathrm{Cu}$ content. Effects of conventional and organic production systems were significant on Fe content of lettuce leaves in the second year, but it was not significant in the first year. Although the differences were not significant among treatments, the lowest value for Fe content were recorded at the leaves of conventionally produced lettuce during the first year. The conventional production system along with the COF treatment had also the lowest Fe content in the second year while the growing lettuce plants in GM+FYM or unfertilized control plots resulted in the highest Fe content on leaves in this year.

The results showed that there were significant differences in $\mathrm{Mn}$ content among treatments in the production systems in the first year $(p \leq 0.05)$ and the second year $(p \leq 0.01)$ Tab. 4. Conventional production system had higher Mn content than GM+COF treatment, but not differed from other treatments in the first year. The highest Mn content was obtained from the GM treatment while the conventional system resulted with the lowest Mn content in the second year.

All treatments had a significant influence on $\mathrm{Zn}$ content in both years (Tab. 4). Although the conventional system had the lowest $\mathrm{Zn}$ content value in the first year, only the $\mathrm{GM}+\mathrm{COF}$ treatment had statistically higher $\mathrm{Zn}$ content than conventional system. However, the $\mathrm{Zn}$ content of lettuce leaves did not differ among organic treatments in the first year. The higher $\mathrm{Zn}$ values were recorded in the leaves of lettuce grown in GM+FYM $\left(55.7 \mathrm{mg} \mathrm{kg} \mathrm{kg}^{-1}\right)$ and 
252

GM+COF (51.3 $\mathrm{mg} \mathrm{kg}^{-1}$ ) plots comparing to other treatments in the second year. The considerable lower $\mathrm{Zn}$ content was recorded with sole use of COF or conventional production system in the second year.

\section{Discussion}

The effects of the conventional and different organic production systems (green manure, farmyard manure, commercial organic fertilizer and their combinations) on the measured parameters differed greatly among the applications. Average total yields were 51.9 and $57.6 \mathrm{tha}^{-1}$ in the first and second years, respectively. Crop yield was affected by the climatic conditions, length of growing season (Pavlou et al., 2007; Kaplan et al., 2008), the abiotic and biotic stress resistance/tolerance of the variety, production system, crop management (Tüzel $e t$ al., 2013) and type of fertilizer used (Masarirambi et al., 2010). In conventional production system, lettuce yields were 51.3 and $52.3 \mathrm{tha}^{-1}$ in the first and second year, respectively. As shown in Tab. 2, the lettuce yield in the conventional production system was lower than the average total lettuce yield. Previous studies on organic lettuce production reported that inorganic fertilizers resulted in lower yields compared to organic manures in lettuce production (Masarirambi et al., 2010; Maqueda et al., 2011). Similar result was reported by Xu et al. (2005), that vegetables grown with organic fertilizers grew better and resulted in a higher total yield than those grown with chemical fertilizers. Since chemical fertilizers do not possess good characteristics of aggregating the soil particles (Masarirambi et al., 2010). In organic production systems, yield reductions for some crops when compared to conventional production system, were also reported (Kaplan et al., 2008). As a result, the plants produced by inorganic fertilizers showed relatively lower yield compared to organic manures.

Organic soil amendments used in organic production systems increase the levels of soil organic matter. Influence of organic matter on soil physical properties dependents on the amount and type of added organic materials (Herencia et al., 2007). Green manure is one of the alternative ways to increase soil organic matter. Green manuring improves soil quality by increasing the organic matter content of soils (Duyar, 2007). In our study, green manure applications and its combinations were found to be more effective in lettuce plant growth and yield than the mineral fertilization in the conventional production system. Adding of green plant material clearly, could be increased the accumulation of soil organic matter during the growth period of lettuce. The leaves and stems of green plant might decompose very quickly. Mandal et al. (2003) reported that the organic matter and total soil nitrogen concentrations founded to be higher under green manuring treated plots in $0-15 \mathrm{~cm}$ soil layer during the growth of rice and wheat. MacRae and Mehuys (1985) also indicated that the green manuring maintained an elevated soil organic matter level. Similarly, another positive effect of green manure on lettuce could be partly associated with the amounts of plant nutrients in general and $\mathrm{N}$ in particular, returned to soil in legumes biomass (Shah et al., 2011). Mandal et al. (2003) speculated that possible benefit of green manuring to soil nitrogen may be due to nitrogen released from roots and nodules during their growth. Nitrogen is the key element for higher yield and better quality. It is involved in all of the plant's metabolic processes, its rate of uptake and partition being largely determined by supply and demand during the various stages of plant growth (Delogua et al., 1998). Research showed that the yield effect of green manure in soil depends on the amount of $\mathrm{N}$ in biomass, its release rate, the $\mathrm{C} / \mathrm{N}$ ratio in organic matter (Kumar and Goh, 2002), soil $\mathrm{N}$ content and climate. The $\mathrm{C} / \mathrm{N}$ ratio of organic residues added to soil is very important. Green manure $\mathrm{C} / \mathrm{N}$ ratios varied from 20 to 37 , depending on the species. Green manures with lower $\mathrm{C} / \mathrm{N}$ ratios decompose rapidly and have a rapid effect on soil physical properties and on biological activity (Wagger, 1989) and therefore could increase crop yields and N nutrition. Salmeron et al. (2011) reported that the $\mathrm{C} / \mathrm{N}$ rate of common vetch is lower than the other green manure (average of 12.8) and it when planted alone it can provide substantial amounts of $\mathrm{N}$ to the following crop. Improved soil physical and chemical properties by green manuring can lead to the growth of larger and healthier root systems (Thorup-Kristensen, 2006; Mandal et al., 2003) and nutrients may have been uptaken more efficiently. According Becker et al. (1995), even with a short growth period of 45-60 days, green manure legumes can fix 80-100 kg N ha ${ }^{-1}$ of which the major portion (about $80 \%)$ is derived from biological $\mathrm{N}_{2}$ fixation. Sattell et al. (1998) also reported that the common vetch can accumulate approximately $6-14 \mathrm{~kg} \mathrm{~N} / \mathrm{da}^{-1}$. Our results indicated that green manuring with common vetch probably resulted in increasing $\mathrm{N}$ nutrition of lettuce in following season, and consequently head yield increased. The green manuring also improved the organic matter status of soil, which ultimately increased the crop growth and yield of lettuce in both years.

Effects of different organic and conventional production systems were found to be not significant for vitamin $\mathrm{C}, \mathrm{pH}$, soluble solids and total $\mathrm{N}$ content of lettuce leaves in both years (Tab. 3). Although the differences among treatments were not significant statistically, the conventional production system resulted in lower vitamin $\mathrm{C}$ content comparing to all organic systems in the first year. However, the effects of treatments on vitamin $\mathrm{C}$ content were not consistent between years, and some organic treatments had lower values than conventional production system. There are reports of reduced, increased or not changed vitamin C content of different crops grown in organic systems (Worthington, 2001; Masamba and Nguyen, 2008; Citak and Sonmez, 2010). Polat et al. (2008) found vitamin C concentration of lettuce between 12.85-18.23 mg $100 \mathrm{ml}^{-1}$; however, Ismail and Fun (2003) pointed out that

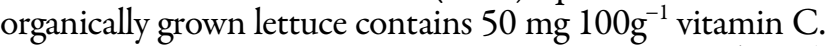
Based on a farming comparison study, Lairon et al. (1984) observed no significant difference in vitamin $\mathrm{C}$ content of lettuce grown organically and conventionally. Those results are in agreement with the findings of this experiment.

Total $\mathrm{N}$ content of lettuce leaves did not differ significantly among the treatments, but it tended to be lower with conventional production system in both years (Tab. 3). It can be expected higher total $\mathrm{N}$ content with mineral fertilization due to adding $\mathrm{N}$ to soil, but some previous studies with lettuce indicating higher $\mathrm{N}$ content in organic systems (Herencia et al., 2007), or no significant 
differences (Lairon et al., 1984).

Manganese, copper, zinc and iron are considered important plant micronutrient. In this study, all applications in the conventional and different organic production systems resulted in significant effects in mineral composition of lettuce leaves in both years, but no significant differences was found in the first year for $\mathrm{Fe}$ content. There was relatively higher copper, iron and zinc contents in plants produced by different organic production systems. Worthington (2001), reported that plants grown in organic environments contained significantly higher $\mathrm{Fe}$ than plants grown in conventional agricultural environments. Kaplan et al. (2008) reported that the Mn contents of lettuce leaves differed significantly between the different organic fertilization practices and mineral fertilization and decreased with the mineral fertilization in both autumn and spring experiments. Zinc is very important mineral for nourishment. Some earlier studies indicated the higher $\mathrm{Zn}$ content of lettuce with organic production systems (Polat $e t$ al., 2008; Kelly and Bateman, 2010), or no significant differences between organic and conventional systems (Maqueda et al., 2011). The mean content of $\mathrm{Zn}$ in the organically grown lettuce is higher than the conventionally grown in our study. In the current study, $\mathrm{Cu}$ contents were significantly higher in the all organic production systems than the conventional system in both years. In earlier studies, there were conflicting reports regarding the effect of organic and mineral fertilization for $\mathrm{Cu}$ content of lettuce leaves. Some researchers have reported that mineral fertilization was the most effective application for the $\mathrm{Cu}$ content (Hernandez et al., 2010; Kaplan et al., 2008) and this result might be due to synergetic effect between $\mathrm{N}$ and $\mathrm{Cu}$ (Aydemir and Ince, 1988). However, some other researchers have reported that mean $\mathrm{Cu}$ concentrations were lower for the conventionally grown lettuce compared to those grown organically (Polat $e t$ al., 2008; Kelly and Bateman, 2010; Maqueda et al., 2011).

Although positive effects of organic amendments on growth and yield traits of lettuce, our study clearly pointed out the synergistic effects of combined use of organic amendments. The combined use of them (GM+FYM or $\mathrm{GM}+\mathrm{COF}$ ) generally resulted in higher values for most of evaluated traits than their sole use (Tab. 2, 3 and 4). Increasing organic matter of soil increases the uptake both macro and micro nutrients from the soil by crops (Herrick and Wander, 1998). The organic amendments used in the study have some advantages over each others. Hence combined use of them probably generated multiple benefits of different contributions from each organic amendments.

\section{Conclusion}

The results of current study indicated that lettuce growth and yield were greatly affected by applied agricultural production systems. Lettuce yield of grown in the organic production systems was higher than the conventional production system. The lowest plant growth and yield were recorded in the non-fertilizer applied control treatment. The most significant impact on growth and yield was observed when green manure was applied to soil. Green manure increased lettuce yields when applied with farmyard manure. In addition, lettuce grown in the green manure and farmyard manure applications showed higher mineral content than those grown in conventional production system. Therefore, combined use green manure and farmyard manure applications were best suited for organic lettuce production with high yield and better quality.

\section{Acknowledgements}

This study was supported by The State Planning Organization of Turkey (DPT) under the research project number $03 \mathrm{~K} 120860$. The authors wish to thank to the DPT for financial support.

\section{References}

Aydemir O, Ince F (1988). Plant nutrition. p. 211-276. Dicle University, Education Faculty, Press, 2. Turkey

Becker M, Ladh JK, Ali M (1995). Green manure technology: potential, usage, and limitations. A case study for lowland rice. Plant Soil 174:181-194.

Citak S, Sönmez S (2009). Mineral contents of organically and conventionally grown spinach (Spinacea oleracea L.) during two successive seasons. J Agr Food Chem 57:7892-7898.

Citak S, Sönmez S (2010). Effects of conventional and organic fertilization on spinach (Spinacea oleracea L.) growth, yield, vitamin $\mathrm{C}$ and nitrate concentration during two successive seasons. Scientia Horticulturae 126:415-420.

Delogua G, Cattivelli L, Pecchioni N, De Falcis D, Maggiore T, Stanca AM (1998). Uptake and agronomic efficiency of nitrogen in winter barley and winter wheat. Eur J Agron 9:1120.

Deshpande SS, Solunkhe DK (1998). Handbook of vegetable science and technology, p.493-509, Marcel Dekker, New York.

Duyar H (2007). Effects of green manuring on greenhouse vegetable production. $\mathrm{PhD}$, Ege University Graduate School of Natural and Applied Sciences, İzmir, Turkey (in Turkish).

FAO (2013). Food and Agriculture Organization Statistical Database. http://faostat3.fao.org/home (Accessed in August, 2013).

Hammad HM, Khaliq A, Ahmad A, Aslam M, Malik AH, Farhad W (2011). Influence of different organic manures on wheat productivity. International Journal of Agriculture and Biology 13:137-140.

Herencia JF, Ruiz-Porras JC, Melero S, Garcia-Galavis PA, Morillo E, Maqueda C (2007). Comparison between organic and mineral fertilization for soil fertility levels, crop macronutrient concentrations, and yield. Agron J 99:973-983.

Hernandez A, Castillo H, Ojeda D, Arras A, Lopez J, Sanchez E (2010). Effect of vermicompost and compost on lettuce production. Chilean Journal Agricultural Research 70:583589.

Herrick JE, Wander MM (1998). Relationship between soil organic carbon and soil quality in cropped and rangeland soils: the importance of distribution, composition and soil biological activity. In: Advances in soil science: Soil processes and the carbon cycle (Eds. Lal R, Kimble J, Follet R, Stewart 
254

BA), CRC Press LLC, Boca Raton, FL, pp. 405-425.

Islam MS, Ahmed A, Mahmud S, Tusher TR, Khanom S (2012). Effects of organic fertilizer on the growth and yield of lettuce (Lactuca sativa L.) used as vegetables. Int J Agric Sci 2:116128.

Ismail A, Fun CS (2003). Determination of vitamin C, $\beta-$ carotene and riboflavin contents in five green vegetables organically and conventionally grown. Malaysian Journal of Nutrition 9:31-39.

Kacar B, Inal A (2008). Analyses of plant, Nobel Press No:1241, Ankara, Turkey.

Kamberoglu MA, Alan B (2011). Occurrence of tomato spotted wilt virüs in lettuce in Cukurova region of Turkey. International Journal of Agriculture and Biology 13:431-434.

Kaplan M, Sonmez S, Polat E, Demir H (2008). Effects of organic and mineral fertilizers on yield and nutritional status of lettuce. Asian J Chem 20:1915-1926.

Kelly SD, Bateman AS (2010). Comparison of mineral concentrations in commercially grown organic and conventional crops - Tomatoes (Lycopersicon esculentum L.) and lettuces (Lactuca sativa L). Food Chem 119:738-745.

Kumar K, Goh KM (2002). Management practices of antecedent leguminous and non-leguminous crop residues in relation to winter wheat yields, nitrogen uptake, soil nitrogen mineralization and simple nitrogen balance. Eur J Agron 16:295308.

Lairon D, Termine E, Gautier S, Trouilloud M, Lafont H, Hauton JC (1984). Effects of organic and mineral ferlizations on the contents of vegetables in minerals, vitamin $\mathrm{C}$ and nitrates. In: The importance of biological agriculture in a world of diminishing resources. H Vogtmann, E Boehncke \& I Fricke (eds). Witzenhausen, Germany.

MacRae RJ, Mehuys GR (1985). The effect of green manuring on the physical properties of temperate-area soils. Advances in Soil Science 3:71-94.

Mandal UK, Singh G, Victor US, Sharma KL (2003). Green manuring: its effect on soil properties and crop growth under rice-wheat cropping system. Eur J Agron 19:225-237.

Masamba KG, Nguyen M (2008). Determination and comparison of vitamin $\mathrm{C}$, calcium and potassium in four selected conventionally and organically grown fruits and vegetables. African Journal of Biotechnology 7:2915-2919.

Masarirambi MT, Hlawe MM, Oseni OT, Sibiya TE (2010). Effects of organic fertilizers on growth, yield quality and sensory evaluation of red lettuce (Lactuca sativa L) 'Veneza Roxa'. Agriculture and Biology Journal of North America $1(6): 1319-1324$.
Maqueda C, Herencia JF, Ruiz JC, Hidalgo MF (2010). Organic and inorganic fertilization effects on DTPA-extractable Fe, $\mathrm{Cu}, \mathrm{Mn}$ and $\mathrm{Zn}$, and their concentration in the edible portion of crops. J Agr Sci 149:461-472.

Nelson DV, Sommers LE (1980). Total nitrogen analysis of soil and plant tissues. J Assoc Off Anal Chem 63:770-778.

Pavlou GC, EhaliotisCD, Kavvadias VA (2007). Effect of organic and inorganic fertilizers applied during successive crop seasons on growth and nitrate accumulation in lettuce. Scientia Horticulturae 111:319-325.

Pearson D (1970). Analysis. Detemination of L-ascorbic acid. International Federation of Fruit Juice Producers (No:17).

Polat E, Demir H, Onus AN (2008). Comporison of some yield and quality criteria organically and conventionally-grown lettuce. African Journal of Biotechnology 7:1235-1239.

Salmeron M, Isla R, Cavero J (2011). Effect of winter cover crop species and planting methods on maize yield and availability under irrigated Mediterranean conditions. Field Crop Res 123:89-99.

SAS Institute Inc. (1996). SAS/STAT users guide, ver. 6.4th ed. Carry, NC.

Sattell R, Dick R, Luna J, Mc Grath D, Peachey E (1998). Common vetch (Vicia sativa L.). In:Oregon cover crops. Oregon State University Extension Service, Corvallis.

Shah Z, Ahmad SR, Rahman HU, Shah MZ (2011). Sustaining rice-wheat system through manrgement of legumes II. Effect of gren manure legumes and fertilizer on wheat yield. Pakistan J Bot 43(4):2093-2097.

Stewart WM, Dibb DW, Jonston AE, Smyth TJ (2005). The contribution of commercial fertilizer nutrients to food production. Agron J 97:1-6.

Talgre L, Lauringson E, Roostalu H, Astover A, Makke A (2012). Green manure as a nutrient source for succeeding crops. Plant Soil and Environment 58: 275-281.

Thorup-Kristensen K (2006). Root growth and nitrogen uptake of carrot, early cabbage, onion and lettuce following a range of green manures. Soil Use Man 22:29-38.

Vural H, Esiyok D, Duman I (2000). Culture vegetables (Vegetables growing). Ege U., Agriculture Faculty, Department of Horticulture, Bornova, Izmir, $400 \mathrm{p}$.

Wagger MG (1989). Time of dessication effects on plant composition and subsequent nitrogen release from several winter annual cover crops. Agron J 81:236-241.

Worthington V (2001). Nutritional quality of organic versus conventional fruits, vegetables and grains. J Altern Complem Med 7:161-173.

Xu HL, Wang R, Xu RY, Mridha MAU, Goyal S (2005). Yield and quality of leafy vegetables grown with organic fertilizations. Acta Horticulturae 627:25-33. 